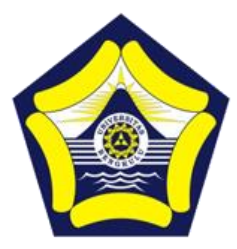

\title{
Development of Organic Chemistry Module with 4D Model to Improve Students' Creative Thinking Abilities
}

\author{
Witra Lili *, M. Lutfi Firdaus, Agus Sundaryono \\ Graduate School of Science Education, University of Bengkulu \\ *Email: witrapsr@gmail.com
}

DOI: https://doi.org/10.33369/bjset.2.1.16-19

\begin{abstract}
The aims of this study were to determine the level of feasibility of the modules developed and to increase students' creative thinking skills in the Organic Chemistry of Natural Products subject. Module development was carried out with the 4D model, namely Define, Design, Develop, and Disseminate. The feasibility of the module could be determined through the validation test with expert judgments. The ability to think creatively by students was measured using descriptive questions based on creative thinking indicators, fluency, flexibility, and elaboration. Measurements were made by comparing the results of the pretest and posttest. Next the results were tested for normality and hypothesis testing using the SPSS 20 program through the One Sample Kolmogorov-Smirnov Test. Based on the validation test by expert judgments, the modules that have been prepared have a module level of eligibility which was very valid or very feasible. The average for each indicator of creative thinking at pretest and posttest has increased. The pretest and posttest values on fluency indicators were 15.31 and 35.62 with N-gain 0.78 high category, flexible thinking (20.62 and 62.81 with Ngain 0.88 high category, and elaboration) 33.43 and 61.24 with $\mathrm{N}$-gain 0.73 in the high category. After the normality test, and the hypothesis test, it was concluded that there was an increase in students' creative thinking abilities in the Organic Chemistry of Natural Products course with the use of modules.
\end{abstract}

Keywords: Module, Model 4D, Creative Thingking, Pretest, Posttest.

\section{INTRODUCTION}

Organic Chemistry of Natural Products (KOBA) is one of the elective courses for students of the S1 Chemistry Education Study Program Faculty of Teacher Training and Education, University of Bengkulu with a weight of 2 credits consisting of 2 theoretical credits. One of the materials in the KOBA course is to explain ways of isolation and identification for natural substance compounds. Learning outcomes in the KOBA course are students who can explain ways of isolation and identification of natural compounds and their applications in life. Based on these indicators, it can be interpreted that students are targeted to master the concept of KOBA in depth. So, students must have the ability to think highly, one of them thinking creatively. Base on, education in the 21 st century, which integrates knowledge skills, skills and attitudes, as well as mastery of Information and Communication Technology (ICT). 21st century education has a competency orientation from LOTS (Lower Order Thinking Skills) to HOTS (Higher Order Thinking Skills). HOTS (Higher Order Thinking Skills) consists of critical thinking, creative thinking, logical, reflective, and metacognitive (King et al, 2008). The levels of remembering, understanding and applying are categorized as low level thinking skills (LOTS). While the levels of analyzing, evaluating and creating are categorized as higher order thinking skills (HOTS) (Anderson et al, 2001).

Creative thinking is an original and reflective thought based on available data or information to find many possible answers to a problem where the emphasis is on the quantity, accuracy and diversity of answers. The ability to think creatively involves the activity of synthesizing ideas, building new ideas and determining their effectiveness and involving the ability to make decisions and produce new products. The characteristics of creative thinking are fluency, flexibility, and elaboration (Munandar, 1999). If someone applies creative thinking in solving a problem, many ideas will arise in solving the problem. One that can be used to foster creative ideas is teaching material that presents information. 
Teaching material is an important subject in the learning process to help students achieve learning goals. Broadly speaking instructional material or instructional material includes knowledge, skills and attitudes that students learn in order to achieve predetermined competencies (Trianto, 2012). Without teaching materials the teaching and learning process will not run. Therefore, educators who will teach must have and master the teaching materials that will be delivered to students (Widia, 2015). Mumford (2013) states that teaching materials can also play a role in students' creative thinking abilities. Modules are one of the teaching materials that can be used as a learning resource for students and as a source of material or teaching guides for a lecturer. The module plays a very important role because it has a function as an independent learning material for students who have summarized a variety of target.

\section{RESEARCH METHODS}

The research conducted was Research and Development (R and D) with a 4-D model, namely Define, Design, Develop, and Disseminate. The subjects in this study were 32 students of Chemistry Education in FKIP Bengkulu University. The subjects used in this study were selected using the purposive sampling method. According to Sugiyono (2010), purposive sampling is a sampling technique with certain considerations. In the define phase, an initial analysis was carried out to gather information and needs needed in the research process, including the analysis of module requirements, semester program plans and basic competencies, and materials.

The design phase was carried out in drafting and designing the KOBA module design. The develop phase of the module and the test questions that have been made are validated with expert judgment. Module validity data was calculated by the formula (Sugiyono, 2005):

Table 1. Validity Criteria

$$
\mathrm{P}=\frac{f}{n} \mathrm{x} 100 \%
$$

Note: $\quad P=$ Percentage of Rating

$\mathrm{f}=$ Score obtained

$\mathrm{n}=$ Overall score

\begin{tabular}{|c|c|}
\hline Percentage & Validity Criteria \\
\hline $82 \%-100 \%$ & Very valid \\
\hline $63 \%-81 \%$ & Valid \\
\hline $44 \%-62 \%$ & Invalid \\
\hline $25 \%-43 \%$ & Very Invalid \\
\hline
\end{tabular}

Valid questions and modules would be tested on a small scale to students of semester VIII who have taken KOBA courses and learned about the material to be tested. The small scale test aimed to determine the validity of the test items, reliability, level of difficulty, and different power. The disseminate stage was carried out with a pretest test, module distribution, and posttest test. The results of creative thinking skills obtained from pretest and posttest were tested for normality, and hypothesis testing to determine the effect of using modules on the learning process. The normality test and hypothesis were carried out using the SPSS 20 program through the One Sample Kolmogorov-Smirnov Test.

\section{RESULTS AND DISCUSSION}

Based on the syllabus analysis, competency standards (SK) and basic competencies (KD) were obtained which were further developed into learning indicators in module design. The module structure was the initial part consisting of a cover, preface, and table of contents, list of images, and a list of tables. The core part consisted of introduction and learning. Introduction included usage instructions, competency standards, learning objectives, concept maps, and mastery of competency standards. Learning included a description of the material in which was equipped with stimulation questions to encourage students' creative thinking skills, material summary, and stimulus list of creative thinking. The concluding part consisted of the aims and objectives of the evaluation, evaluation questions, bibliography, and glossary.

Then, the module was validated to find out feasibility and suggestions for improvement validated by a chemistry education expert lecturer with aspects of content eligibility, aspects of presentation eligibility, aspects of language assessment and overall assessment. Validation test results indicated that every aspect was declared valid or feasible. So, the module was ready to be applied to students in the KOBA learning process. 
The initial test (Pretest) was given to students to find out the initial abilities possessed by students before the use of modules in the learning process, while the final test (posttest) aimed to determine the final abilities possessed by students after the use of the module. This research was conducted 3 meetings. At the first meeting, a pretest was held, the second meeting was the distribution of modules, and the third meeting was held a posttest. The questions used in the pretest and posttest were the same problem and in the form of description. Three indicators were used to measure students' creative thinking abilities, namely fluency (fluent thinking), flexibility (flexible thinking), and elaboration (detailed thinking). The total score of the three indicators was stated in the average value of students' creative thinking abilities.

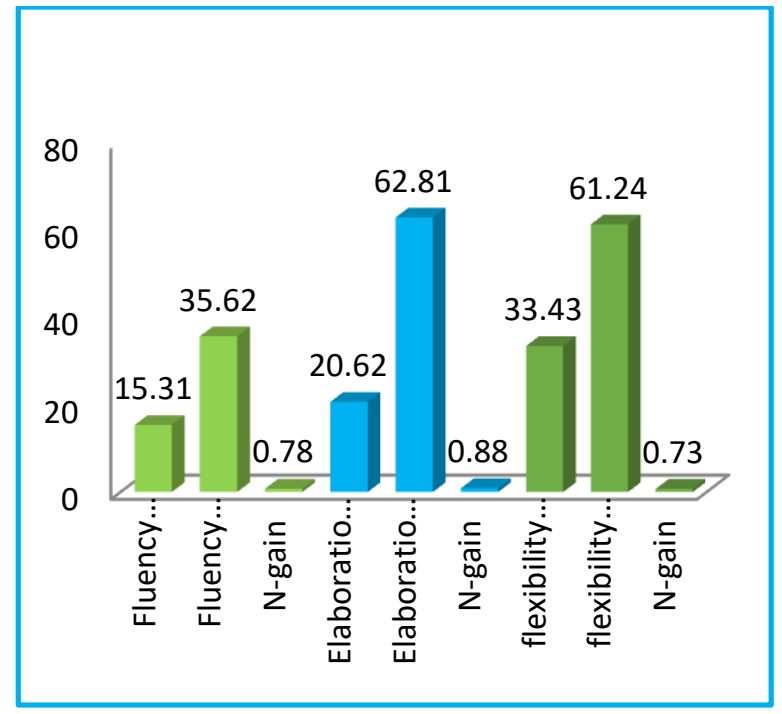

Figure 1. Increasing students' creative thinking skills

Based on Figure 1, the average posttest score has better results than the pretest. These results indicate there has been an increase in students' creative thinking abilities each indicator thinks creatively and also the $\mathrm{N}$-gain value. The pretest and posttest values on fluency indicators were 15.31 and 35.62 with $\mathrm{N}$-gain 0.78 high category, flexible thinking (20.62 and 62.81 with $\mathrm{N}$-gain 0.88 high category, and elaboration) 33.43 and 61.24 with $\mathrm{N}$-gain 0.73 in the high category. In general, the N-Gain value obtained was in the high category. $\mathrm{N}$-Gain values in the N-Gain range > 0.7 were high categories (Hake and Reece, 1999).

Table 2. Normality Test

One-Sample Kolmogorov-Smirnov Test

\begin{tabular}{|c|c|c|c|}
\hline & & PRETEST & POSTTEST \\
\hline$N$ & & 32 & 32 \\
\hline \multirow[t]{2}{*}{ Normal Parameters ${ }^{a, b}$} & Mean & 75,63 & 128,13 \\
\hline & Std. Deviation & 13,183 & 13,545 \\
\hline \multirow[t]{3}{*}{ Most Extreme Differences } & Absolute & ,193 & 212 \\
\hline & Positive &, 151 & , 195 \\
\hline & Negative &,- 193 &,- 212 \\
\hline Kolmogorov-Smirnov Z & & 1,089 & 1,198 \\
\hline Asymp. Sig. (2-tailed) & & ,186 &, 113 \\
\hline
\end{tabular}

a. Test distribution is Normal.

b. Calculated from data.

The pretest and posttest values that have been obtained were then analyzed to determine the normality test and hypothesis test. Based on the results of the analysis of normality test, data with the SPSS 20 program 
through the One Sample Kolmogorov-Smirnov Test with test criteria if the significance value obtained was more than 0.05 then the data was normally distributed (Arikunto, 2009). The results could be seen in the following table 2. Based on table 2, it can be observed that the test results of the Pretest score obtained the value of Asymp.sig. (2-tailed) $=0.186$. This value was more than 0.05 , so it could be concluded that the pretest data was normally distributed. For the posttest test results obtained Asymp.sig value (2-tailed) = 0.113. This value was more than 0.05 , so it could be concluded that the posttest data was normally distributed.

Homogeneity test was carried out by Paired-Samples $\mathrm{T}$ Test. Paired-Samples $\mathrm{T}$ Test was part of the comparative hypothesis test or comparison test. The data used in the Paired Samples T Test was generally in the form of interval or ratio scale data (quantitative data). Paired-Samples T Test was a part of the parametric statistical analysis. Therefore, as a basic rule in parametric statistical analysis the main requirement was that research data must be normally distributed. Table 3 was the results of the hypothesis test: Based on the table 3 , hypothesis test was obtained by the value of Sig (2-tailed) $=0.000$, this value was $<\alpha(0.05)$, then H0 was rejected and Ha was accepted. Thus, there was an increase in the ability to think creatively with learning to use modules in semester VI students of Chemistry Education FKIP UNIB.

Tabel 3. The Result of The Hypothesis Test

\begin{tabular}{|c|c|c|c|c|c|c|c|c|}
\hline \multicolumn{9}{|c|}{ Paired Samples Test } \\
\hline & \multicolumn{5}{|c|}{ Paired Differences } & \multirow[b]{3}{*}{$t$} & \multirow[b]{3}{*}{$d f$} & \multirow[b]{3}{*}{ Sig. (2-tailed) } \\
\hline & \multirow[b]{2}{*}{ Mean } & \multirow[b]{2}{*}{ Std. Deviation } & \multirow{2}{*}{$\begin{array}{c}\text { Sto. Error } \\
\text { Mean }\end{array}$} & \multicolumn{2}{|c|}{$\begin{array}{l}95 \% \text { Confidence Interval of the } \\
\text { Difference }\end{array}$} & & & \\
\hline & & & & Lower & Upper & & & \\
\hline Pair 1 PRETEST-POSTTEST & $.52,500$ & 10,776 & 1,905 & $.56,385$ & $-48,, 615$ & $.27,559$ & 31 &, 000 \\
\hline
\end{tabular}

\section{CONCLUSION}

Based on the results of the validation test, it was concluded that the Organic Chemistry of Natural Products module was declared valid or feasible. So, modules can be used in Organic Chemistry of Natural Products learning. The ability to think creatively in semester VI students of Chemistry Education FKIP Bengkulu University has increased. It can be seen from the average value of each indicator in the pretest and posttest.

\section{REFERENCES}

Anderson, L. W., Krathwohl, D. R., Airasian, P. W., Cruikshank, K. A., Mayer, R. E., Pintrich, P. R., et al. (2001). A Taxonomy for Learning, Teaching, and Assissing: A Revision of Bloom's Taxonomy of Educational Objectives. New York: Longman.

Arikunto, S. 2009. Prosedur Penelitian Suatu Pendekatan Praktik. Edisi Revisi 6. Jakarta : Rineka Cipta.

Hake, R. R., Reece, J. G. 1999. Analyzing change/gain scores. Psychology. Published 1999.

Munandar, Utami. 1999. Kreativitas dan Keberbakatan: Strategi Mewujudkan Potensi Kreatif dan Bakat. Jakarta: Gramedia Pustaka Utama.

King, FJ., Goodson, L., Rohani, F. 2008. Higher Order Thinking Skills: Definitioin, Teaching Strategies, Assessment. A publication of the Educational Services Program, now known as the Center for Advancement of Learning and Assessment. www.cala.fsu.edu.

Mumford, M. D., Giorgini, V., Gibson, C., \& Mecca, J. (2013). Creative thinking: Processes, strategies and knowledge. In Handbook of research on creativity. Edward Elgar Publishing.

Prastowo A. 2012. Pengembangan Sumber Belajar. Pedagogia: Yogyakarta.

Sugiyono. 2005. Metode Statistika. Rosdakarya: Bandung.

Sugiyono. 2010. Metode Penelitian Pendidikan (Pendekatan Kuantitatif, Kualitatif, dan R\&D). Alfabeta: Bandung.

Trianto, 2010. Model Pembelajaran Terpadu. Jakarta: Bumi Aksara.

Wati, W. (2015). Pengembangan Modul Pembelajaran Fisika SMA Terintegrasi Penanggulangan Bencana Tanah Longsor. Jurnal Ilmiah Pendidikan Fisika Al-Biruni, 4(1), 109-119. 